\title{
Preparation of Eggshell-Type $\mathrm{Ru} / \mathrm{Al}_{2} \mathrm{O}_{3}$ Catalysts for Hydrogen Production Using Steam-Methane Reforming on PEMFC
}

\author{
Jong-Heon Lee ${ }^{1,+}{ }^{\text {, Seongbin Jo }}{ }^{2,+}{ }^{\mathbb{D}}$, Tae-Young Kim ${ }^{1}{ }^{\mathbb{D}}$, Jin-Hyeok Woo ${ }^{1}$, Yeji Lee ${ }^{3}$, Min-Seok Kim ${ }^{4}$, \\ Hye-Ok Park ${ }^{5}$, Soo-Chool Lee ${ }^{3, *}$ and Jae-Chang Kim ${ }^{1, * \mathbb{D}}$ \\ 1 Department of Chemical Engineering, Kyungpook National University, Daegu 41566, Korea; \\ rnswma123@knu.ac.kr (J.-H.L.); tyoung0218@knu.ac.kr (T.-Y.K.); wjh8865@knu.ac.kr (J.-H.W.) \\ 2 Department of Chemical and Environmental Engineering, University of California-Riverside, \\ Riverside, CA 92521, USA; sjo016@ucr.edu \\ 3 Research Institute of Advanced Energy Technology, Kyungpook National University, Daegu 41566, Korea; \\ yejeelee@knu.ac.kr \\ 4 S-Fuelcell, Suwon 16648, Korea; minseok.kim@s-fuelcell.com \\ 5 Sudokwon Landfill Site Management Corporation, Incheon 22688, Korea; hioki07@slc.or.kr \\ * Correspondence: soochool@knu.ac.kr (S.-C.L.); kjchang@knu.ac.kr (J.-C.K.) \\ + Jong-Heon Lee and Seongbin Jo contributed equally to this work.
}

\section{check for}

updates

Citation: Lee, J.-H.; Jo, S.; Kim, T.-Y.; Woo, J.-H.; Lee, Y.; Kim, M.-S.; Park,

H.-O.; Lee, S.-C.; Kim, J.-C.

Preparation of Eggshell-Type

$\mathrm{Ru} / \mathrm{Al}_{2} \mathrm{O}_{3}$ Catalysts for Hydrogen

Production Using Steam-Methane

Reforming on PEMFC. Catalysts 2021,

11, 951. https://doi.org/10.3390/

catal11080951

Academic Editor:

Paraskevi Panagiotopoulou

Received: 8 July 2021

Accepted: 4 August 2021

Published: 9 August 2021

Publisher's Note: MDPI stays neutral with regard to jurisdictional claims in published maps and institutional affiliations.

Copyright: (c) 2021 by the authors. Licensee MDPI, Basel, Switzerland. This article is an open access article distributed under the terms and conditions of the Creative Commons Attribution (CC BY) license (https:// creativecommons.org/licenses/by/ $4.0 /)$.

\begin{abstract}
Ru-based eggshell-type catalysts, in which Ru is located at the outer region of the pellet, were prepared by the impregnation method, using spherically shaped $\gamma-\mathrm{Al}_{2} \mathrm{O}_{3}$ pellets for steammethane reforming (SMR). Ru was only supported on the external region of the pellet because of the strong interaction between its precursor and the alumina pellet. The Ru precursor penetrated the inside of the pellet by adding nitric acid to the impregnation solution. The distribution and thickness of the $\mathrm{Ru}$ layer in the catalyst can be controlled using the $\mathrm{HNO}_{3} / \mathrm{Ru}$ molar ratio and contact time at the impregnation step. Among the catalysts, the graded eggshell-type catalyst showed the highest activity and long-term stability in the SMR reaction. In addition, in the daily startup and shutdown (DSS) operation, similar to the hydrogen production environment for domestic polymer electrolyte membrane fuel cells (PEMFC), the graded eggshell-type catalyst showed high activity and stability after multiple cycles. Based on the experimental studies, it was confirmed that Ru-based catalysts are suitable for steam-methane reforming for PEMFC.
\end{abstract}

Keywords: eggshell-type catalyst; fuel cell; steam-methane reforming; daily startup and shutdown operation

\section{Introduction}

Hydrogen is a prospective energy carrier and it has attracted attention because it can be stored and transported, efficiently, and burns to produce only water as a byproduct. Among the various ways of using hydrogen, polymer electrolyte membrane fuel cells (PEMFCs) are employed in residential fuel cells due to their large energy density, high calorific value, and abundant resources [1]. Residential fuel cells are designed to operate with city gas supplied through well-developed pipeline infrastructures. Thus, the $\mathrm{H}_{2}$ gas will be generated onsite by reforming available fuels, such as natural gas (mostly methane), before the fuel gas enters the fuel cell stack. Several processes for producing hydrogen using methane reforming are available: steam reforming, dry reforming, partial oxidation, etc. [2-4]. Steam-methane reforming (SMR) is the most commonly used process, described by Equation (1). The reformer operates at high temperatures (1073 K-1373 K) because SMR is an endothermic reaction, and the steam is fed more than $\mathrm{CH}_{4}$ to avoid coke formation, based on methane decomposition (2) and the Boudouard reaction (3).

$$
\mathrm{CH}_{4}+\mathrm{H}_{2} \mathrm{O} \rightarrow \mathrm{CO}+3 \mathrm{H}_{2}, \Delta \mathrm{H}_{298 k}=206 \mathrm{kJmol}^{-1}
$$




$$
\begin{gathered}
\mathrm{CH}_{4} \rightarrow 2 \mathrm{H}_{2}+\mathrm{C}, \Delta H_{298 k}=75.3 \mathrm{kJmol}^{-1} \\
2 \mathrm{CO} \rightarrow \mathrm{CO}_{2}+\mathrm{C}, \Delta H_{298 k}=-172.3 \mathrm{kJmol}^{-1}
\end{gathered}
$$

Various types of catalysts are used to increase the efficiency of this process [4-12]. Noble metals, such as $\mathrm{Ru}, \mathrm{Rh}$, and Pt catalysts, show high catalytic activity, even at a low concentration, and have resistance to coking or active metal oxidation, which is a disadvantage of nickel catalysts. Experimental and kinetic studies on various noble metal catalysts have been reported. In particular, $\mathrm{Ru}$ has displayed a high reforming activity compared to other noble metals, such as Ir and Pt [9-13]. This indicated that $\mathrm{Ru}$ is a promising catalyst for methane reforming.

To operate in a fixed-bed configuration, on an industrial scale, catalytically active components should be supported on an inert porous pellet to avoid the pressure drop inside the fixed-bed reactors. In addition, in the case of a catalyst using pellet-type support, the distribution of catalytically active components is various such as eggshell, egg-yolk, and homogeneous type [14-17]. This difference in the distribution of catalytically active components depends on the strength of the metal precursor-support interactions and may appear as a difference in activity in the reaction. In the platinum catalyst on alumina, where the interaction between the platinum precursor and aluminum is strong, the distribution of the platinum precursor has been adjusted using various additives [14,15]. The generally accepted description of the strong metal precursor-support interaction is the revised physical adsorption model provided by Spieker and Regalbuto [18]. Porta et al. reported that varied distributions of a metal precursor, which interact strongly with the support, can be obtained through the addition of an inorganic acid to the impregnating solution. This is because the acid addition is expected to decrease the $\mathrm{pH}$ of the impregnating solution, thereby reducing the surface potential of the alumina. Consequently, it reduces the interaction between the negatively charged Ru complex and the support [16].

In this study, $\mathrm{Ru}$ catalysts supported on spherical-shaped $\gamma-\mathrm{Al}_{2} \mathrm{O}_{3}$ pellets were prepared using the impregnation method. They showed various distributions of Ru by controlling the $\mathrm{HNO}_{3} / \mathrm{Ru}$ molar ratio and impregnating contact time in the catalyst-synthesizing process. The effect of Ru distribution on catalytic activity in the SMR reaction was investigated. The catalytic activity and stability, in daily startup and shutdown (DSS) operation, of the selected eggshell-type catalyst was evaluated. Moreover, the $\mathrm{Ru} / \gamma-\mathrm{Al}_{2} \mathrm{O}_{3}$ was analyzed using Brunauer-Emmett-Teller (BET) analysis, X-ray diffraction (XRD), scanning electron microscopy (SEM) with energy-dispersive $X$-ray spectroscopy (EDS), and wavelength-dispersive X-ray fluorescence spectrometry (XRF).

\section{Results and Discussion}

\subsection{Characteristics of the $\mathrm{Ru} / \gamma-\mathrm{Al}_{2} \mathrm{O}_{3}$ Catalysts}

Prepared catalysts are designated as $\mathrm{RA}(\mathrm{a}, \mathrm{b} \mathrm{h})$, where " $\mathrm{RA}$ " indicates " $\mathrm{Ru} / \mathrm{Al}_{2} \mathrm{O}_{3}$ " catalysts, "a" designates the $\mathrm{HNO}_{3} / \mathrm{Ru}$ molar ratio, and " $\mathrm{b}$ " indicates the contact time (e.g., $\mathrm{RA}(10,1 \mathrm{~h})$ is a catalyst with an $\mathrm{HNO}_{3} / \mathrm{Ru}$ molar ratio of 10 and a contact time of $1 \mathrm{~h}$.)

Figure 1 shows (a) external surface and (b) cross-sectional images of prepared catalysts using a digital microscope, based on the $\mathrm{HNO}_{3} / \mathrm{Ru}$ molar ratio and contact time. All pellets had a black color due to $\mathrm{Ru}$ oxide, and the surface increased in brightness with the $\mathrm{HNO}_{3} / \mathrm{Ru}$ molar ratio when the contact time was $1 \mathrm{~h}$. This is because alumina can be redeposited on the catalyst surface, in highly acidic environments, during the precipitation and $\mathrm{Ru}$ can be covered [19]. Figure $1 \mathrm{~b}$ shows that, in the absence of $\mathrm{HNO}_{3}, \mathrm{Ru}$ was loaded only on the external surface of the pellet because of the strong metal precursor-support interaction, regardless of the contact time (delimited eggshell-type catalyst). In the presence of $\mathrm{HNO}_{3}$, $\mathrm{Ru}$ for catalysts penetrated the pellet. 


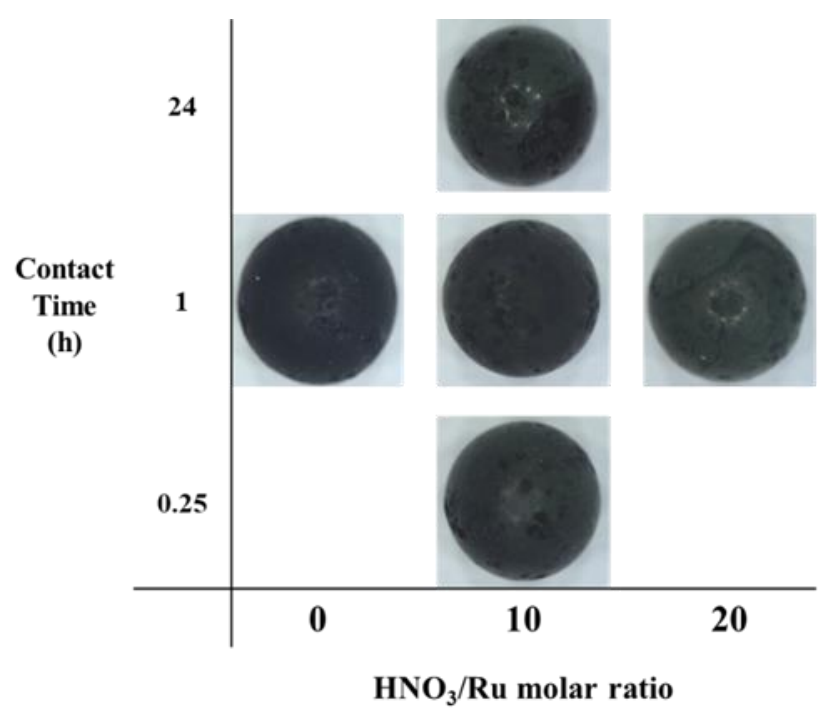

(a)

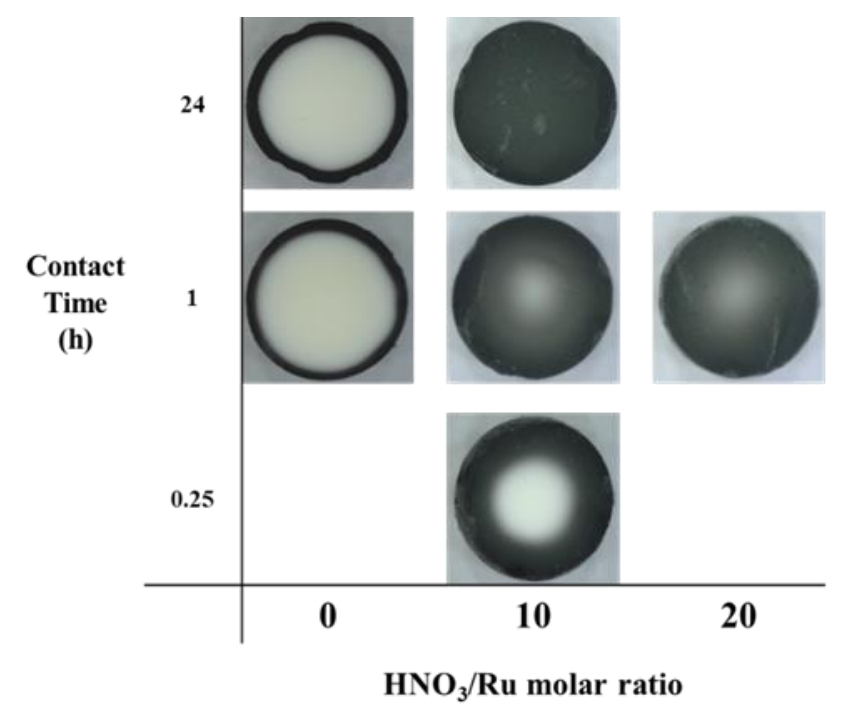

(b)

Figure 1. (a) External surface and (b) cross-sectional images of prepared catalysts.

In addition, the $\mathrm{Ru}$ distribution in the pellet interior was different, depending on the $\mathrm{HNO}_{3} / \mathrm{Ru}$ molar ratio and the contact time. Ru penetrated the pellets better as the $\mathrm{HNO}_{3} / \mathrm{Ru}$ molar ratio increased. The difference in contact time exhibited a notable difference inside the pellet when the $\mathrm{HNO}_{3} / \mathrm{Ru}$ molar ratio was fixed at 10 . The $\mathrm{RA}(10,0.25 \mathrm{~h})$ showed the eggshell profile, indicating that the concentration of Ru was low in the center of the pellet. When the contact time reached $1 \mathrm{~h}$, i.e., (RA $(10,1 \mathrm{~h})$ ), the boundary became more blurred. RA $(10,24 \mathrm{~h})$ with sufficient contact time showed a uniform color distribution (homogeneous type). The shell thickness of the eggshell layer could be effectively adjusted by controlling the $\mathrm{HNO}_{3} / \mathrm{Ru}$ molar ratio and contact time until a homogeneously impregnated pellet was obtained.

To investigate the distribution of the pellets inside the $\mathrm{Ru}$, the concentration of $\mathrm{Ru}$ was measured using SEM-EDS in the cross-section of the catalysts from the edge to the center (Figure 2). Figure 2a shows the difference in Ru distribution based on the $\mathrm{HNO}_{3} / \mathrm{Ru}$ molar ratio. For the RA $(0,1 \mathrm{~h})$ catalyst, a high concentration of Ru was detected only on the external surface of the catalyst ( $\mathrm{r} / \mathrm{R}$ of $\sim 0.05$ ). This is because the strong metal precursor-support interaction prevented the $\mathrm{Ru}$ precursor from penetrating the pellet. However, $\mathrm{Ru}$ was found inside the pellet when $\mathrm{HNO}_{3}$ was added. The concentration of the $\mathrm{Ru}$ inside the pellet gradually increased as the amount of the $\mathrm{HNO}_{3}$ added in the impregnation solution increased, whereas the concentration of Ru on the external surface of the pellet decreased. In addition, we confirmed the relationship between the distribution of $\mathrm{Ru}$ and contact time in Figure $2 \mathrm{~b}$. The total Ru concentration of RA (10, $0.25 \mathrm{~h})$ inside a pellet was less than those of the others. For the homogeneous catalyst (RA $(10,24 \mathrm{~h})$ ), the concentration of Ru was similar $(\sim 2 \mathrm{wt} \%)$ in all regions, including the external surface of the pellet. The change in Ru concentration, on the external surface, decreased with the contact time. 

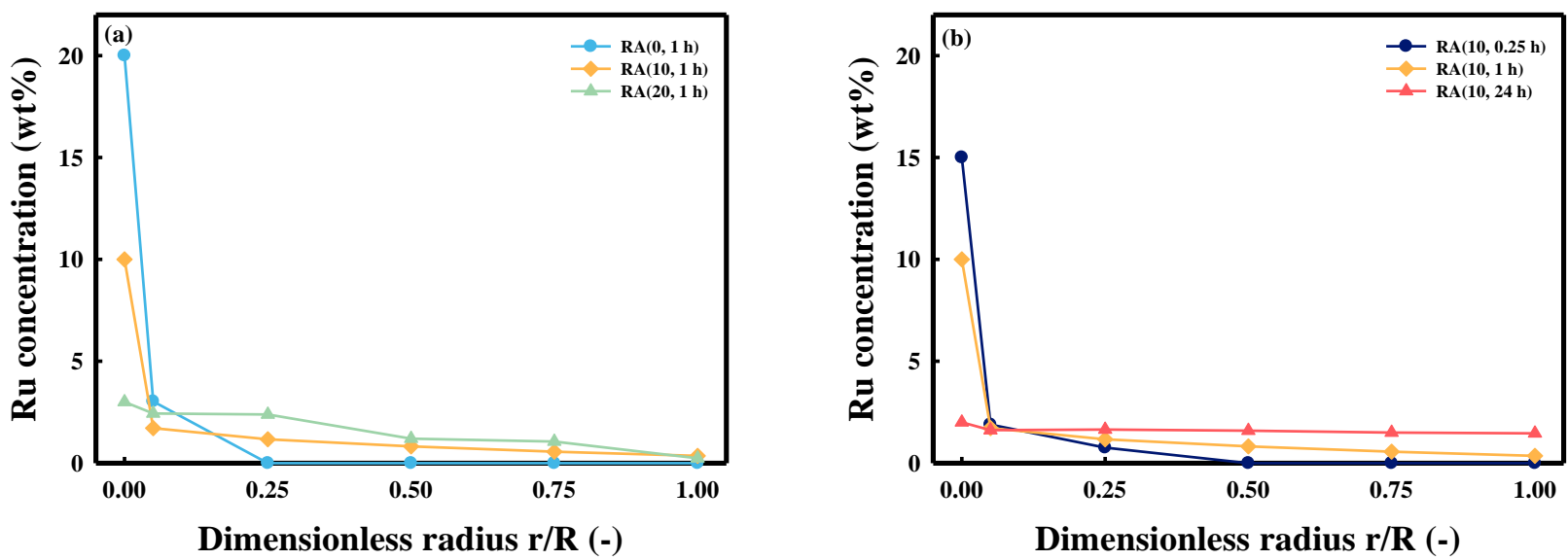

Figure 2. Ru concentration profile measured in prepared catalysts by SEM-EDS: (a) different $\mathrm{HNO}_{3} / \mathrm{Ru}$ molar ratio; (b) different contact times.

Figure 3a shows the XRD patterns of calcined $\mathrm{Ru} / \gamma-\mathrm{Al}_{2} \mathrm{O}_{3}$ catalysts with different $\mathrm{HNO}_{3} / \mathrm{Ru}$ molar ratios. In addition to the $\gamma$-alumina peaks (JCPDS No. 04-0875), the catalysts showed $\mathrm{RuO}_{2}$ peaks (JCPDS No. 73-1469); their intensity decreased with $\mathrm{HNO}_{3} / \mathrm{Ru}$ molar ratio. After the reduction, the peaks corresponding to $\mathrm{RuO}_{2}$ disappeared, and peaks of Ru metal (JCPDS No. 07-0274) were observed, which means that all Ru oxide was reduced through a reduction process. The calculated $\mathrm{RuO}_{2}$ and $\mathrm{Ru}$ crystallite sizes decreased with the increase in the amount of nitric acid (Table S1). In the absence of $\mathrm{HNO}_{3}$, the crystallite sizes of $\mathrm{RuO}_{2}$ and $\mathrm{Ru}$ metal were larger than the others. In addition, the XRD patterns were almost the same, regardless of the contact time, when $\mathrm{HNO}_{3} / \mathrm{Ru}$ molar ratio was 10 (Figure S1). In contrast to $\mathrm{RuO}_{2}$ and $\mathrm{Ru}$, no change in the $\gamma$-alumina peaks was observed based on the differences in reduction, contact time, and amount of nitric acid. The BET surface area, pore size, pore volume, and $\mathrm{Ru}$ content of $\mathrm{Ru} / \mathrm{Al}_{2} \mathrm{O}_{3}$ catalysts in the calcined and reduced states were almost the same, regardless of the molar ratio or contact time (Table S1).
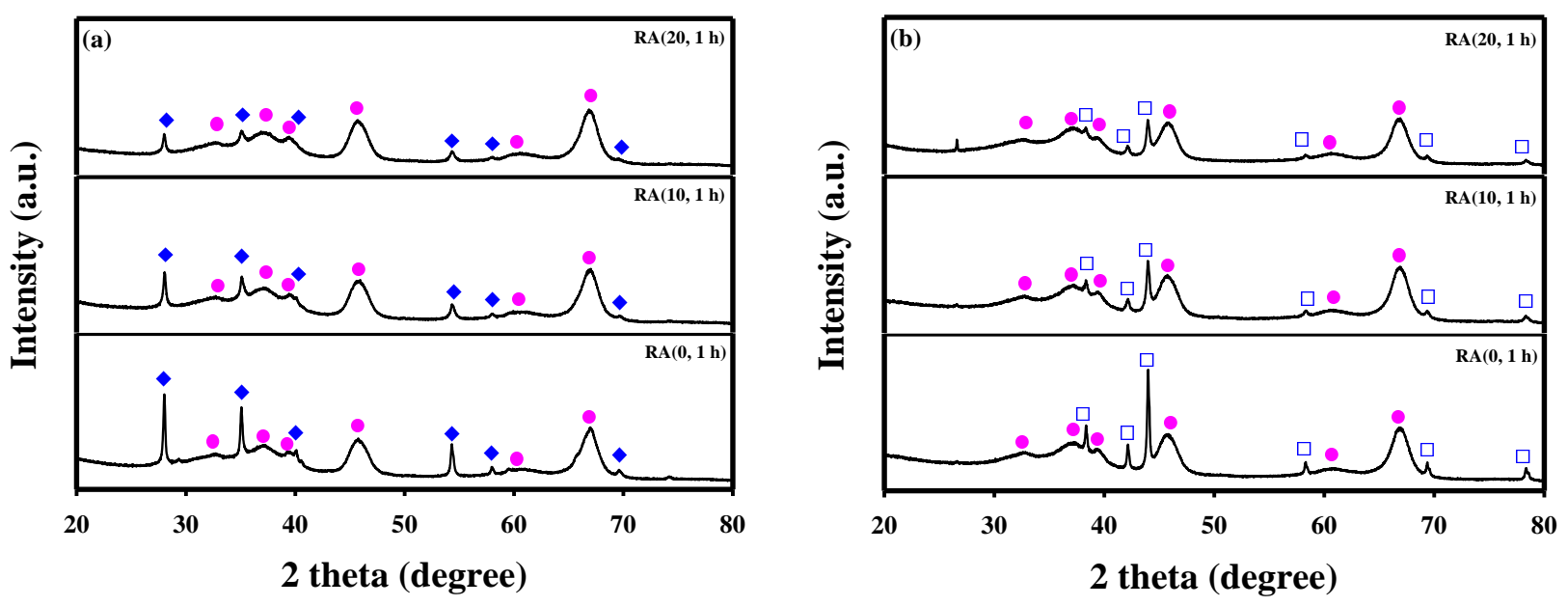

Figure 3. XRD patterns of the $\mathrm{Ru} / \mathrm{Al}_{2} \mathrm{O}_{3}$ catalysts with different $\mathrm{HNO}_{3} / \mathrm{Ru}$ molar ratios in its fresh (a) and reduced (b) states. $(\bullet) \gamma-\mathrm{Al}_{2} \mathrm{O}_{3},(\diamond) \mathrm{RuO}_{2}$, and $(\square)$ metallic Ru.

\subsection{Catalytic Performance of the $\mathrm{Ru} / \gamma-\mathrm{Al}_{2} \mathrm{O}_{3}$ Catalysts}

\subsubsection{Catalytic Test in Long-Term Stability Test}

Figure 4 shows the $\mathrm{CH}_{4}$ conversion as a function of time on stream (T.O.S) for five kinds of $\mathrm{Ru} / \mathrm{Al}_{2} \mathrm{O}_{3}$ catalysts. Figure $4 \mathrm{a}$ shows that $\mathrm{RA}(0,1 \mathrm{~h})$ exhibited the lowest initial 
$\mathrm{XCH}_{4}(\sim 91 \%)$. On the other hand, RA $(10,1 \mathrm{~h})$ and RA $(20,1 \mathrm{~h})$ showed higher catalytic activities than RA $(0,1 \mathrm{~h})$ did. The RA $(10,1 \mathrm{~h})$ catalyst showed the highest $\mathrm{XCH}_{4}(98 \%)$, close to the equilibrium conversion $(98 \%)$. The RA $(20,1 \mathrm{~h})$ catalyst showed slightly lower $\mathrm{XCH}_{4}$ because RA $(10,1 \mathrm{~h})$ showed a higher Ru concentration on the external surface of pellets. In the absence of $\mathrm{HNO}_{3}$, the catalyst (RA $(0,1 \mathrm{~h})$ ) was deactivated (from $91 \%$ to $72 \%)$ due to the poisoning of $\mathrm{NH}_{3}$ by the byproduct of the reaction $\left(\mathrm{N}_{2}+3 \mathrm{H}_{2}=2 \mathrm{NH}_{3}\right)$ [20]. The RA $(0,1 \mathrm{~h})$ catalyst did not show deactivation when nitrogen was replaced with argon (Figure S2). Deactivation was not observed with RA (10, $1 \mathrm{~h}$ ), even in a nitrogen atmosphere, and this difference seemed to be due to the smaller Ru crystallite size. From these results, we confirmed that the addition of $\mathrm{HNO}_{3}$ increased the $\mathrm{Ru}$ dispersion, but not the methane conversion [21]. The CO selectivity of RA $(0,1 \mathrm{~h})$ was lower than those of other catalysts, attributed to the water-gas shift reaction (WGS, $\mathrm{CO}+\mathrm{H}_{2} \mathrm{O}=\mathrm{CO}_{2}+\mathrm{H}_{2}$ ) (Figure 5a) [22]. During the SMR reaction using the RA (0, $1 \mathrm{~h}$ ) catalyst, more water was available because of the lower $\mathrm{CH}_{4}$ conversion, thus increasing the $\mathrm{H}_{2} \mathrm{O} / \mathrm{CO}$ ratio, favoring WGS equilibrium. In the case of $\mathrm{RA}(10,1 \mathrm{~h})$, the $\mathrm{CO}, \mathrm{CO}_{2}$ carbon-based selectivity did not change over time; however, the $\mathrm{CO}$ selectivity of RA $(0,1 \mathrm{~h})$ decreased because the methane conversion rate decreased with T.O.S. (Figure S3). For this reason, the $\mathrm{H}_{2} / \mathrm{CO}$ ratio of the $\mathrm{RA}(0,1 \mathrm{~h})$ catalyst was higher than those of other catalysts (Table S2). When the $\mathrm{HNO}_{3} / \mathrm{Ru}$ molar ratio was 10, the activity of the SMR reaction was similar for all catalysts because of the similar Ru crystallite size (Figure $4 b$ ). In addition, Figure $5 \mathrm{~b}$ shows that the selectivity of catalysts with a fixed $\mathrm{HNO}_{3} / \mathrm{Ru}$ molar ratio at 10 was not significantly different.

In the long-term stability test, the catalytic activity was slightly different, depending on the Ru distribution on pellets. The RA $(0,1 \mathrm{~h})$ catalyst showed a lower SMR activity than the other catalysts did due to the poisoning of $\mathrm{NH}_{3}$. This is a disadvantage because the $\mathrm{H}_{2}$ gas entering the fuel cell will be generated onsite by reforming natural gas, including $\mathrm{N}_{2}$ gas. The homogeneous catalysts (RA $(10,24 \mathrm{~h})$ ) showed a similar catalytic activity to graded eggshell-type catalysts (RA $(10,1 \mathrm{~h}))$; however, it required longer preparation times.
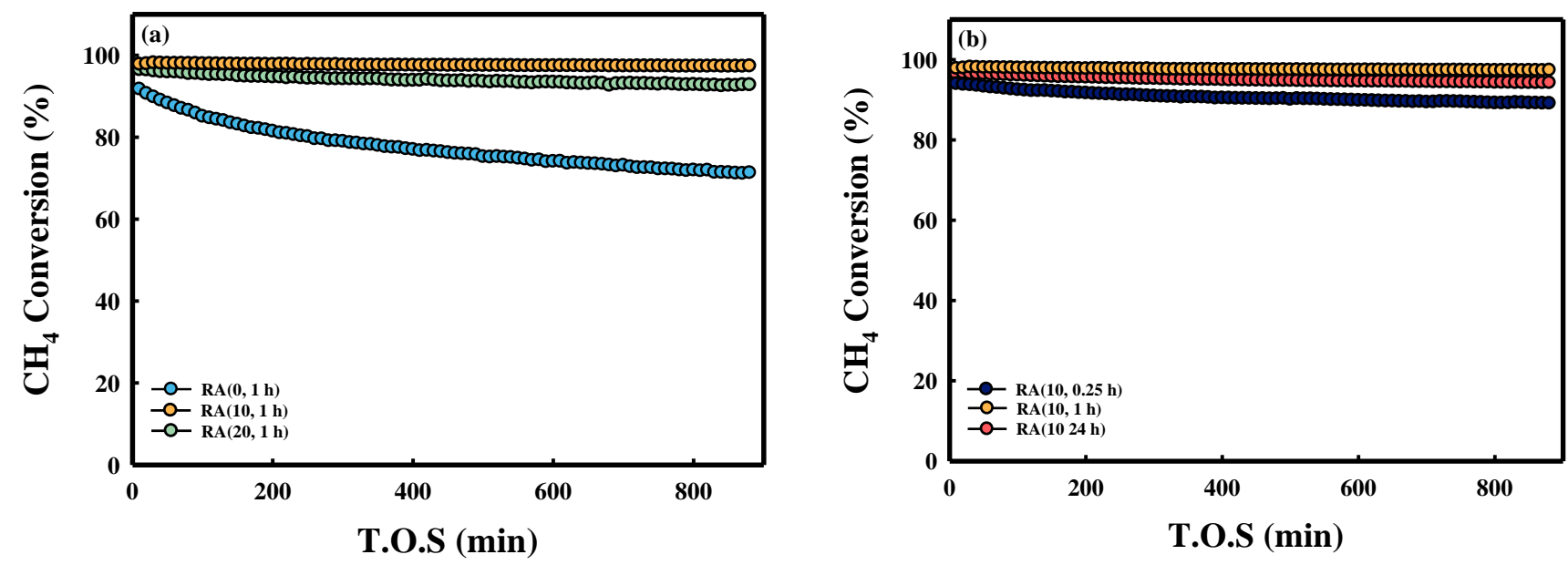

Figure 4. Long-term stability tests of the $\mathrm{Ru} / \mathrm{Al}_{2} \mathrm{O}_{3}$ catalysts in the $\mathrm{SMR}$ reaction at $700{ }^{\circ} \mathrm{C}, \mathrm{S} / \mathrm{C}$ ratio of 3 , and WHSV of $12,000 \mathrm{~mL} / \mathrm{g} / \mathrm{h}$ : (a) different $\mathrm{HNO}_{3} / \mathrm{Ru}$ molar ratios and contact time fixed at $1 \mathrm{~h} ;(\mathbf{b}) \mathrm{HNO}_{3} / \mathrm{Ru}$ molar ratio fixed at 10 and different contact times.

Figure 6 shows the $\mathrm{XRD}$ patterns of spent $\mathrm{Ru} / \gamma-\mathrm{Al}_{2} \mathrm{O}_{3}$ catalysts. No difference was observed between the reduced and spent catalysts in any catalyst. In addition, no coke diffraction peaks in the XRD patterns of the catalysts were observed. The BET surface areas and average pore sizes of spent catalysts changed after $15 \mathrm{~h}$ of reaction (Table 1). However, compared to the reduced catalysts, the Ru crystallite sizes of all catalysts did not change after the reaction. Figure S4 shows the SEM images of the prepared and the spent $\mathrm{Ru} / \gamma-\mathrm{Al}_{2} \mathrm{O}_{3}$ catalysts with a fixed contact time at $1 \mathrm{~h}$. For all catalysts, there was no significant difference between the prepared and the spent catalysts. 

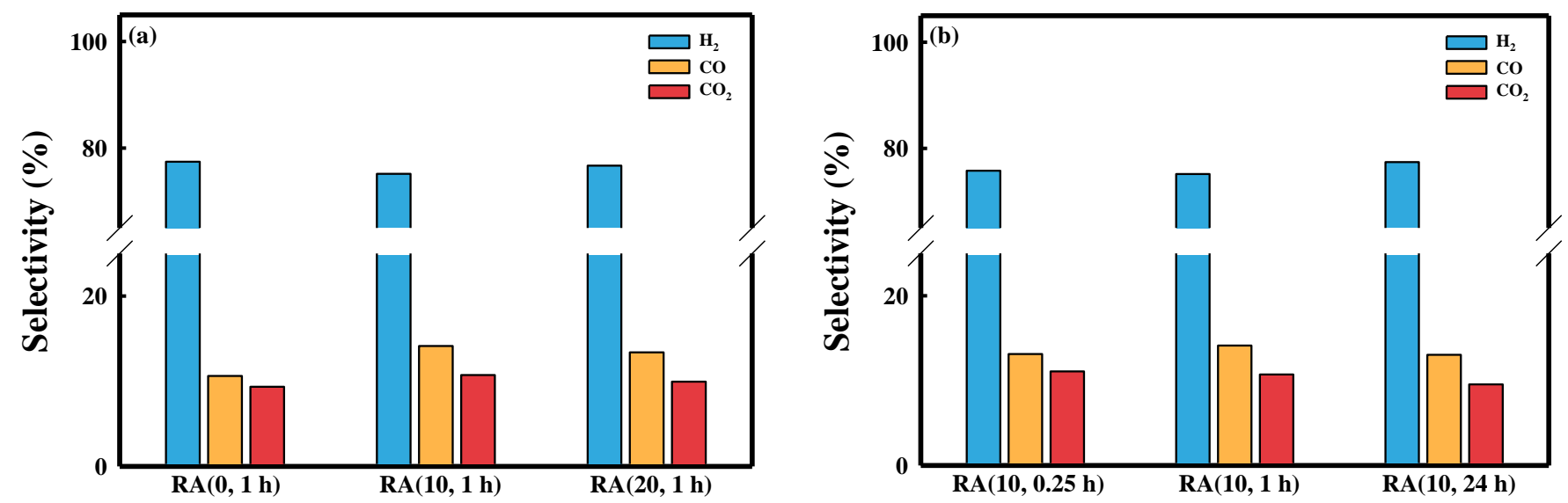

Figure 5. Selectivity in long-term stability tests of the $\mathrm{Ru} / \mathrm{Al}_{2} \mathrm{O}_{3}$ catalysts: (a) different $\mathrm{HNO}_{3} / \mathrm{Ru}$ molar ratios and contact time fixed at $1 \mathrm{~h}$; (b) $\mathrm{HNO}_{3} / \mathrm{Ru}$ ratio fixed at 10 and different contact times.
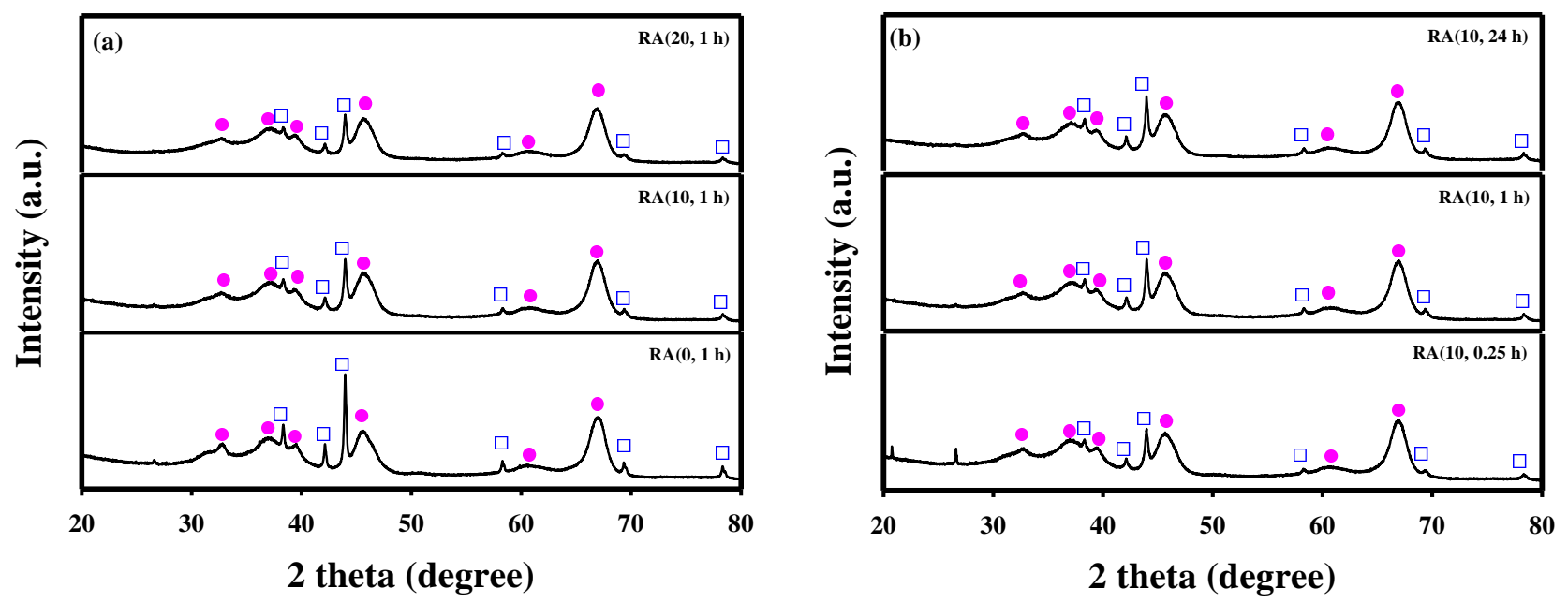

Figure 6. XRD patterns of the $\mathrm{Ru} / \mathrm{Al}_{2} \mathrm{O}_{3}$ catalysts after long-term stability tests: (a) different $\mathrm{HNO}_{3} / \mathrm{Ru}$ molar ratios and contact time fixed at $1 \mathrm{~h} ;(\mathbf{b}) \mathrm{HNO}_{3} / \mathrm{Ru}$ ratio fixed at 10 and different contact times.

Table 1. BET surface area, pore volume, average pore size, and $\mathrm{Ru}$ crystallite size of $\mathrm{Ru} / \mathrm{Al}_{2} \mathrm{O}_{3}$ catalysts in their spent states.

\begin{tabular}{|c|c|c|c|c|}
\hline Sample & $\begin{array}{l}\text { BET Surface } \\
\text { Area }\left(\mathrm{m}^{2} / \mathrm{g}\right)\end{array}$ & $\begin{array}{l}\text { Pore Volume } \\
\qquad\left(\mathrm{cm}^{3} / \mathrm{g}\right)\end{array}$ & $\begin{array}{c}\text { Average Pore } \\
\text { Size (nm) }\end{array}$ & $\begin{array}{l}\text { Ru Crystallite } \\
\text { Size (nm) }\end{array}$ \\
\hline $\mathrm{RA}(0,1 \mathrm{~h})$ & 143 & 0.50 & 10.2 & 43.8 \\
\hline RA $(10,0.25 \mathrm{~h})$ & 153 & 0.49 & 9.4 & 25.7 \\
\hline RA $(10,1 \mathrm{~h})$ & 156 & 0.49 & 9.5 & 27.2 \\
\hline $\mathrm{RA}(10,24 \mathrm{~h})$ & 151 & 0.49 & 9.5 & 27.5 \\
\hline $\mathrm{RA}(20,1 \mathrm{~h})$ & 154 & 0.50 & 9.8 & 23.5 \\
\hline
\end{tabular}

\subsubsection{Catalytic Test in DSS Operation}

To confirm the efficiency of the actual fuel cell, the RA $(10,1 \mathrm{~h})$ catalyst showing the best activity and stability was tested in DSS operation [23]. Before the catalytic test, the catalyst was reduced in an $\mathrm{H}_{2} / \mathrm{N}_{2}$ gas mixture $(10 / 90 \mathrm{~mL} / \mathrm{min})$ for $3 \mathrm{~h}$ at $800{ }^{\circ} \mathrm{C}$. After the reduction, the catalysts were cooled to $700{ }^{\circ} \mathrm{C}$ under $\mathrm{N}_{2}$ gas, and then the reaction was started in a $\mathrm{CH}_{4} / \mathrm{H}_{2} \mathrm{O} / \mathrm{N}_{2}(10 / 30 / 60 \mathrm{~mL} / \mathrm{min})$. After a $90 \mathrm{~min}$ reaction, the catalysts were cooled to $200{ }^{\circ} \mathrm{C}$ at a rate of $10{ }^{\circ} \mathrm{C} / \mathrm{min}$ under purge conditions. The purge condition consisted of $\mathrm{H}_{2} \mathrm{O} / \mathrm{N}_{2}(30 / 60 \mathrm{~mL} / \mathrm{min})$ in which only the $\mathrm{CH}_{4}$ supply was stopped under 
reaction conditions. After the catalysts bed temperature was maintained at $200{ }^{\circ} \mathrm{C}$ for $30 \mathrm{~min}$, the temperature was increased to $700{ }^{\circ} \mathrm{C}$ under purge conditions. $\mathrm{CH}_{4}$ gas was added to start the reaction; the reaction was held for $90 \mathrm{~min}$. To perform the DSS operation, this reaction was repeated 5 times. The results of the DSS operation are shown in Figure 7. RA (10, $1 \mathrm{~h}$ ) showed no significant deactivation during the 5 cycles of DSS operation. The catalyst prepared using an appropriate $\mathrm{HNO}_{3} / \mathrm{Ru}$ molar ratio and contact time was suitable for SMR reaction.

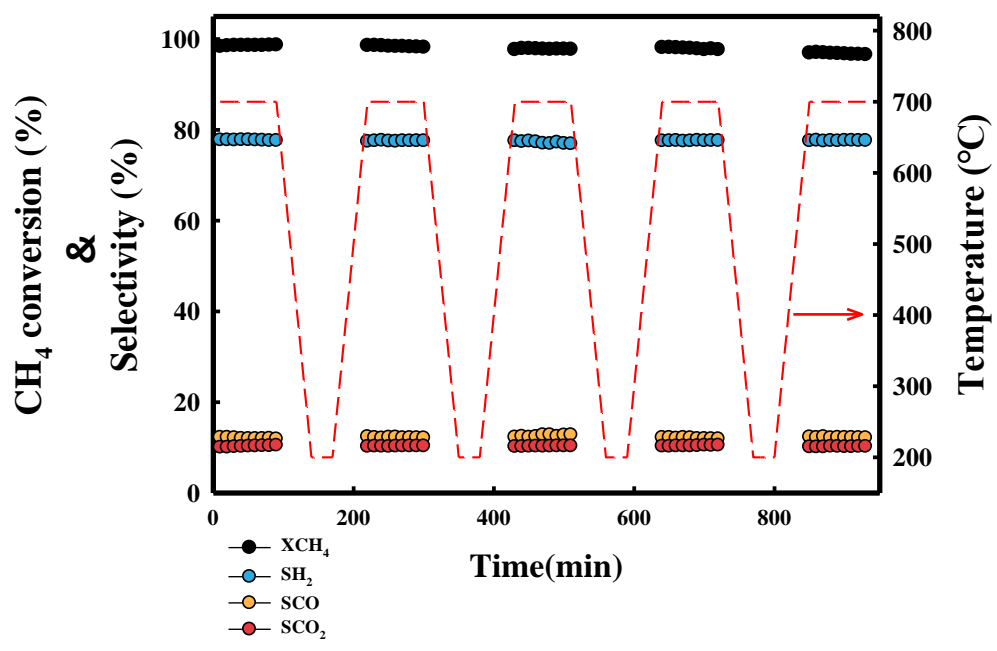

Figure 7. Methane conversion and selectivity of RA (10, $1 \mathrm{~h})$ catalyst in DSS operation.

\section{Materials and Methods}

\subsection{Materials}

The $\mathrm{Ru}(\mathrm{III})$ nitrosyl nitrate $\left(\mathrm{Ru}\left(\mathrm{NO}_{3}\right)_{3}(\mathrm{NO}), \mathrm{Ru} 31.3 \% \mathrm{~min}\right)$ was purchased from AlfaAesar (Ward Hill, MA, USA). Spherical-shaped $\gamma-\mathrm{Al}_{2} \mathrm{O}_{3}$ pellets were purchased from SASOL (Sandton, South Africa). $\mathrm{HNO}_{3}(64-66 \mathrm{wt} \%$ ) was purchased from DUKSAN (AnSan, Korea).

\subsection{Catalysts Preparation}

All catalysts were synthesized using impregnation methods. Before preparation, the pellet was dried at $150{ }^{\circ} \mathrm{C}$ for $2 \mathrm{~h}$. The $\mathrm{Ru}$ concentration was $2 \mathrm{wt} \%$ based on $\mathrm{Ru} / \gamma-\mathrm{Al}_{2} \mathrm{O}_{3}$, and the nitric acid was added based on the molar ratio of $\mathrm{Ru}$. The desired amount of pellets, $\mathrm{Ru}(\mathrm{III})$ nitrosyl nitrate, and $\mathrm{HNO}_{3}$ were dispersed in deionized water, and the mixture was stirred at different contact times, for each catalyst. The mixed solution was evaporated in an oven at $150{ }^{\circ} \mathrm{C}$ for $5 \mathrm{~h}$ and calcined in a muffle furnace, under air, at $700{ }^{\circ} \mathrm{C}$ for $4 \mathrm{~h}$; the temperature ramp rate was $10^{\circ} \mathrm{C} / \mathrm{min}$.

\subsection{Characterization}

Cross-sectional images of the catalysts after preparation were observed using a DinoLite Premier Digital Microscope (AM3113T, AnMo Electronics Corp., New Taipei City, Taiwan). The change in the Ru concentrations inside the alumina pellet was measured using scanning electron microscopy (FE-SEM, SU-8230, Hitachi, Tokyo, Japan) with EDS (Oxford Instruments, Abingdon, UK). The crystal structure of the catalysts was analyzed using a $\mathrm{Cu}$ $\mathrm{K} \alpha$ radiation source in a Phillips X'PERT X-ray diffractometer (PANalytical, Amsterdam, Netherlands) located at the Korea Basic Science Institute, Daegu. The surface area, pore volume, and pore size were measured by the BET method, using ASAP2020 (Norcross, GA, USA). The chemical composition of catalysts was measured using a wavelength-dispersive X-ray fluorescence spectrometer (XRF, Bruker Corp., Billerica, MA, USA). 


\subsection{Steam-Methane Reforming Tests}

The SMR tests were determined using gas chromatography (GC). The $\mathrm{Ru} / \mathrm{Al}_{2} \mathrm{O}_{3}$ pellets $(0.5 \mathrm{~g})$ were packed into a fixed-bed reactor with a diameter of $\frac{1}{2}$ inch $(1.27 \mathrm{~cm})$, and the reactor was placed in an electric furnace at atmospheric pressure. The thermocouple was placed at the center of the catalyst bed. Before the SMR, $10 \mathrm{vol} \% \mathrm{H}_{2}$ and $\mathrm{N}_{2}$ balance at $100 \mathrm{~mL} / \mathrm{min}$ (WHSV: $12,000 \mathrm{~mL} / \mathrm{g} / \mathrm{h}$ ) were passed through the packed bed at $800{ }^{\circ} \mathrm{C}$ for $3 \mathrm{~h}$ to reduce the catalysts. After purging the reactor with $\mathrm{N}_{2}$, the reaction temperature was fixed at $700{ }^{\circ} \mathrm{C}$, and the gas composition was changed to $30 \mathrm{vol} \% \mathrm{H}_{2} \mathrm{O}, 10 \mathrm{vol} \% \mathrm{CH}_{4}$ (steam/carbon ratio: 3), and $\mathrm{N}_{2}$ balance at $100 \mathrm{~mL} / \mathrm{min}$. To prevent the condensation of water vapor, the inlet and outlet lines of the reactor were maintained at $120{ }^{\circ} \mathrm{C}$ using heating tape. In addition, the reactor outlet stream was passed through a condenser to capture water before entering the reactor and GC column. The dried gases were analyzed using a gas chromatograph (Agilent 6890, Agilent Technologies, Inc., Santa Clara, CA, USA), equipped with two thermal conductivity detectors (TCDs). The first Carboxen 1000-packed column was connected to one TCD for analysis of the $\mathrm{N}_{2}, \mathrm{CO}, \mathrm{CH}_{4}$, and $\mathrm{CO}_{2}$ gases, and the second Carboxen 1000-packed column was connected to the other TCD for analysis of the $\mathrm{H}_{2}$ gas.

The conversion of $\mathrm{CH}_{4}\left(\mathrm{XCH}_{4}\right)$ and selectivity of the products $\left(\mathrm{CO}, \mathrm{CO}_{2}\right.$, and $\left.\mathrm{H}_{2}\right)$ were calculated using Equations (4)-(7)

$$
\begin{gathered}
X_{\mathrm{CH}_{4}}=\frac{F_{C H_{4}}^{\text {in }}-F_{\mathrm{CH}}^{\text {out }}}{F_{\mathrm{CH}}^{\text {in }}} \times 100 \\
S_{\mathrm{CO}}=\frac{F_{\mathrm{CO}}^{\text {out }}}{F_{\mathrm{CO}}^{\text {out }}+F_{\mathrm{CO}}^{\text {out }}+F_{H_{2}}^{\text {out }}} \times 100 \\
S_{\mathrm{CO}_{2}}=\frac{F_{\mathrm{CO}_{2}}^{\text {out }}}{F_{\mathrm{CO}}^{\text {out }}+F_{\mathrm{CO}}^{\text {out }}+F_{\mathrm{H}_{2}}^{\text {out }}} \times 100 \\
S_{\mathrm{H}_{2}}=\frac{F_{\mathrm{H}_{2}}^{\text {out }}}{F_{\mathrm{CO}}^{\text {out }}+F_{\mathrm{CO}_{2}}^{\text {out }}+F_{\mathrm{H}_{2}}^{\text {out }}} \times 100
\end{gathered}
$$

\section{Conclusions}

In this study, $\mathrm{Ru} / \mathrm{Al}_{2} \mathrm{O}_{3}$ catalysts were prepared using the impregnation method at various $\mathrm{HNO}_{3} / \mathrm{Ru}$ molar ratios and contact times. $\mathrm{HNO}_{3}$ was added to reduce the strength of the metal precursor-support interactions. In the presence of $\mathrm{HNO}_{3}$, at the impregnation step, Ru penetrated the pellet. Therefore, it is possible to make various types, from delimited eggshell type to homogenous type, by controlling the $\mathrm{HNO}_{3} / \mathrm{Ru}$ molar ratio and contact time. $\mathrm{Ru} / \mathrm{Al}_{2} \mathrm{O}_{3}$ catalysts showed a similar $\mathrm{CH}_{4}$ conversion in the SMR reaction except for $\mathrm{RA}(0,1 \mathrm{~h})$, which showed a low $\mathrm{CH}_{4}$ conversion due to the poisoning of $\mathrm{NH}_{3}$. Among them, the graded eggshell-type $\mathrm{RA}(10,1 \mathrm{~h})$ catalyst showed the best activity (98\%) and stability in the long-term test. In addition, the RA (10, $1 \mathrm{~h}$ ) catalyst needed shorter preparation times than the homogeneous-type catalysts that showed similar catalytic activity. Therefore, the RA $(10,1 \mathrm{~h})$ catalyst was selected as the optimal catalyst in our study. In the DSS operation, which was tested under conditions similar to those of an actual fuel cell, the catalytic activity of the graded eggshell-type RA $(10,1 \mathrm{~h})$ catalyst was maintained for five cycles. Based on the experimental studies, it was confirmed that Ru-based catalysts are suitable for SMR for PEMFC.

Supplementary Materials: The following are available online at https:/ / www.mdpi.com/article/ 10.3390 / catal11080951/s1, Table S1: BET surface area, pore volume, average pore size, $\mathrm{RuO}_{2}, \mathrm{Ru}$ crystallite size, and $\mathrm{Ru}$ content of $\mathrm{Ru} / \mathrm{Al}_{2} \mathrm{O}_{3}$ catalysts in its fresh and reduced states. Table S2: $\mathrm{H}_{2} / \mathrm{CO}$ ratio of the $\mathrm{Ru} / \mathrm{Al}_{2} \mathrm{O}_{3}$ catalysts in SMR reaction long-term stability test at $700{ }^{\circ} \mathrm{C}, \mathrm{S} / \mathrm{C}$ ratio of 3 , and WHSV of $12,000 \mathrm{~mL} / \mathrm{g} / \mathrm{h}$. Figure $\mathrm{S} 1$ : XRD patterns of the $\mathrm{Ru} / \mathrm{Al}_{2} \mathrm{O}_{3}$ catalysts with different contact 
times in its fresh (a) and reduced (b) states. Figure S2: Methane conversion of the RA $(0,1 \mathrm{~h})$ catalysts in SMR reaction under different balance gases. Figure S3: Carbon-based selectivity of the RA $(0,1 \mathrm{~h})$ and RA $(10,1 \mathrm{~h})$ catalysts in the SMR reaction long-term stability test at $700{ }^{\circ} \mathrm{C}, \mathrm{S} / \mathrm{C}$ ratio of 3 , and WHSV of $12,000 \mathrm{~mL} / \mathrm{g} / \mathrm{h}$. Figure S4: SEM images of $\mathrm{Ru} / \gamma-\mathrm{Al}_{2} \mathrm{O}_{3}$ catalysts: (a) RA $(0,1 \mathrm{~h})$, (b) RA $(10,1 \mathrm{~h})$, and (c) RA $(20,1 \mathrm{~h})$

Author Contributions: Conceptualization, J.-H.L., S.J. and M.-S.K.; formal analysis, J.-H.L., T.-Y.K., J.-H.W., Y.L. and H.-O.P.; investigation, J.-H.L., T.-Y.K. and J.-H.W.; supervision, S.-C.L. and J.-C.K.; writing-original draft, J.-H.L. and S.J.; writing-review and editing, S.J. and S.-C.L. All authors have read and agreed to the published version of the manuscript.

Funding: This work was supported by the Korea Evaluation Institute of Industrial Technology (KEIT) and the Ministry of Trade, Industry and Energy (MOTIE) of the Republic of Korea (No. 20015460). This work was also supported by the Sudokwon Landfill Site Management Corporation (SLC) through the joint research.

Institutional Review Board Statement: Not applicable.

Informed Consent Statement: Not applicable.

Data Availability Statement: The data presented in this study are available on request from the corresponding author. Data are contained within the article or supplementary material.

Conflicts of Interest: The authors declare no conflict of interest.

\section{References}

1. Dodds, P.E.; Staffell, I.; Hawkes, A.D.; Li, F.; Grünewald, P.; McDowall, W.; Ekins, P.J. Hydrogen and fuel cell technologies for heating: A review. Int. J. Hydrogen Energy 2015, 40, 2065-2083. [CrossRef]

2. Bian, Z.; Wang, Z.; Jiang, B.; Hongmanorom, P.; Zhong, W.; Kawi, S. A review on perovskite catalysts for reforming of methane to hydrogen production. Renew. Sustain. Energy Rev. 2020, 134, 110291. [CrossRef]

3. Summa, P.; Samojeden, B.; Motak, M. Dry and steam reforming of methane. Comparison and analysis of recently investigated catalytic materials. A short review. Pol. J. Chem. Technol. 2019, 21, 31-37. [CrossRef]

4. Chen, L.; Qi, Z.; Zhang, S.; Su, J.; Somorjai, G.A. Catalytic hydrogen production from methane: A review on recent progress and prospect. Catalysts 2020, 10, 858. [CrossRef]

5. Cho, E.H.; Koo, K.Y.; Lee, H.W.; Park, Y.-K.; Yoon, W.L.; Ko, C.H. Preparation of egg-shell-type Ni/Ru bimetal alumina pellet catalysts: Steam methane reforming for hydrogen production. Int. J. Hydrogen Energy 2017, 42, 18350-18357. [CrossRef]

6. Ligthart, D.; Van Santen, R.; Hensen, E.J.M. Influence of particle size on the activity and stability in steam methane reforming of supported Rh nanoparticles. J. Catal. 2011, 280, 206-220. [CrossRef]

7. Miyata, T.; Li, D.; Shiraga, M.; Shishido, T.; Oumi, Y.; Sano, T.; Takehira, K. Promoting effect of Rh, Pd and Pt noble metals to the $\mathrm{Ni} / \mathrm{Mg}(\mathrm{Al}) \mathrm{O}$ catalysts for the DSS-like operation in $\mathrm{CH}_{4}$ steam reforming. Appl. Catal. A Gen. 2006, 310, 97-104. [CrossRef]

8. Wei, J.; Iglesia, E. Reaction pathways and site requirements for the activation and chemical conversion of methane on Ru- based catalysts. J. Phys. Chem. B 2004, 108, 7253-7262. [CrossRef]

9. Jones, G.; Jakobsen, J.G.; Shim, S.S.; Kleis, J.; Andersson, M.P.; Rossmeisl, J.; Abild-Pedersen, F.; Bligaard, T.; Helveg, S.; Hinnemann, B. First principles calculations and experimental insight into methane steam reforming over transition metal catalysts. J. Catal. 2008, 259, 147-160. [CrossRef]

10. Kikuchi, E.; Tanaka, S.; Yamazaki, Y.; Morita, Y. Steam Reforming of Hydrocarbons on Noble Metal Catalysts (Part 1) The Catalytic Activity in Methane-Steam Reaction. Bull. Jpn. Pet. Inst. 1974, 16, 95-98. [CrossRef]

11. Qin, D.; Lapszewicz, J. Study of mixed steam and $\mathrm{CO}_{2}$ reforming of $\mathrm{CH}_{4}$ to syngas on MgO-supported metals. Catal. Today 1994, 21, 551-560. [CrossRef]

12. Zhang, H.; Sun, Z.; Hu, Y.H. Steam reforming of methane: Current states of catalyst design and process upgrading. Renew. Sustain. Energy Rev. 2021, 149, 111330. [CrossRef]

13. Morales-Cano, F.; Lundegaard, L.F.; Tiruvalam, R.R.; Falsig, H.; Skjøth-Rasmussen, M.S. Improving the sintering resistance of $\mathrm{Ni} / \mathrm{Al}_{2} \mathrm{O}_{3}$ steam-reforming catalysts by promotion with noble metals. Appl. Catal. A Gen. 2015, 498, 117-125. [CrossRef]

14. Mang, T.; Breitscheidel, B.; Polanek, P.; Knözinger, H. Adsorption of platinum complexes on silica and alumina: Preparation of non-uniform metal distributions within support pellets. Appl. Catal. A Gen. 1993, 106, 239-258. [CrossRef]

15. Pinna, F. Supported metal catalysts preparation. Catal. Today 1998, 41, 129-137. [CrossRef]

16. Porta, A.; Falbo, L.; Visconti, C.G.; Lietti, L.; Bassano, C.; Deiana, P. Synthesis of Ru-based catalysts for $\mathrm{CO}_{2}$ methanation and experimental assessment of intraporous transport limitations. Catal. Today 2020, 343, 38-47. [CrossRef]

17. Zhuang, Y.; Claeys, M.; Van Steen, E. Novel synthesis route for egg-shell, egg-white and egg-yolk type of cobalt on silica catalysts. Appl. Catal. A Gen. 2006, 301, 138-142. [CrossRef]

18. Spieker, W.; Regalbuto, J. A fundamental model of platinum impregnation onto alumina. Chem. Eng. Sci. 2001, 56, 3491-3504. [CrossRef] 
19. Fenoglio, R.; Alvarez, W.; Nunez, G.; Resasco, D. Interactions of the Impregnating Solution with the Support during the Preparation of $\mathrm{Rh} / \mathrm{Tio}_{2}$ Catalysts. In Studies in Surface Science and Catalysis; Elsevier: Amsterdam, The Netherlands, 1991; Volume 63, pp. 77-86.

20. Watanabe, F.; Kaburaki, I.; Shimoda, N.; Satokawa, S. Influence of nitrogen impurity for steam methane reforming over noble metal catalysts. Fuel Process. Technol. 2016, 152, 15-21. [CrossRef]

21. Carvalho, L.S.; Martins, A.R.; Reyes, P.; Oportus, M.; Albonoz, A.; Vicentini, V.; do Carmo Rangel, M. Preparation and characterization of $\mathrm{Ru} / \mathrm{MgO}-\mathrm{Al}_{2} \mathrm{O}_{3}$ catalysts for methane steam reforming. Catal. Today 2009, 142, 52-60. [CrossRef]

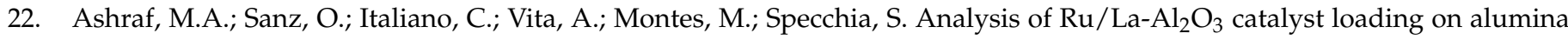
monoliths and controlling regimes in methane steam reforming. Chem. Eng. J. 2018, 334, 1792-1807. [CrossRef]

23. Ohi, T.; Miyata, T.; Li, D.; Shishido, T.; Kawabata, T.; Sano, T.; Takehira, K. Sustainability of Ni loaded Mg-Al mixed oxide catalyst in daily startup and shutdown operations of $\mathrm{CH}_{4}$ steam reforming. Appl. Catal. A Gen. 2006, 308, 194-203. [CrossRef] 